\title{
STUDY OF PALMAR PATTERNS IN CARCINOMA BREAST PATIENTS OF CENTRAL INDIA
}

\section{Prateek Shrivastava ${ }^{1}$, Ankit Jain *2.}

${ }^{1}$ Resident, Department of Anatomy, Mahatma Gandhi Memorial Medical College, Indore (M.P.), India.

${ }^{* 2}$ Assistant professor, Department of Anatomy, Shyam Shah Medical College, Rewa (M.P.), India. ABSTRACT

Background: Breast cancer is very common among females these days, it's occurrence has a strong genetic basis which has been already established. Palmar patterns also develop under genetic control during early development almost at the same period when the mammary buds develop in intrauterine life. And they do not get altered significantly after that, and thus remains almost constant during rest of the life. So these patterns may be assessed as a non-invasive anatomical marker to find the risk of developing breast cancer later in life.

Methodology: In this study assessment of the palmar patterns of both hands of 109 female breast cancer patients were taken and compared with the patterns of 109 age matched normal healthy females. The Patterns were obtained by Ink method in an A4 size white paper. Palmar ridge count (a-b ridge count), palmar angles ( atd angle and adt angle) of both the groups was measured and analysed.

Results: On statistical analysis it was observed that mean a-b ridge count of right and left hands of cases were significantly lower when compared with the mean $a-b$ ridge count of right and left hands of the normal healthy females respectively in Madhya Pradesh.

Conclusion: The palmar ridge counts are significantly associated with breast cancer and in a highly populated country like India with limited medical resources, it may be employed as an inexpensive and effective tool for screening the high-risk population for breast cancer.

KEY WORDS: Palmar Pattern, Breast Cancer, a-b Ridge Count, atd angle, adt angle.

Address for Correspondence: Dr. Ankit Jain, Assistant professor, Department of Anatomy, Shyam Shah Medical College, Rewa (M.P.), India. E-Mail: pshrivastava015@gmail.com

Access this Article online

Quick Response code

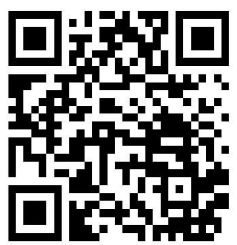

DOI: $10.16965 /$ ijar.2019.152

Journal Information

International Journal of Anatomy and Research

ICV for 2016 ISSN (E) 2321-4287 | ISSN (P) 2321-8967

https://www.ijmhr.org/ijar.htm

DOI-Prefix: https://dx.doi.org/10.16965/ijar

\section{Article Information}

Received: 21 Feb 2019

Peer Review: 21 Feb 2019

Revised: None
Accepted: 07 Apr 2019

Published (O): 05 May 2019

Published (P): 05 May 2019

\section{INTRODUCTION}

Dermatoglyphics is the study of epidermal ridge configuration on palms, soles and fingertips [1]. It's application has been utilised in different areas of anthropology, genetic research, pediatric medicine and psychiatry. The dermal ridges are formed in relation to the volar pads which develop during the $6^{\text {th }}$ week of gestation and reach their maximum size by $12^{\text {th }}$ to $13^{\text {th }}$ week [2].The epidermal ridge patterns that are formed over the surface of the palms and the soles are genetically determined, and establish the concept behind dermatoglyphic examinations in criminal investigations and in medical genetics [3]. Altered chromosome complements affect the development of ridge patterns; for example, about half of the neonates with Down syndrome have specific ridge patterns that are of diagnostic importance [3]. Many diseases due to abnormal genetic configuration have different 
palmar and fingertip patterns associated with them, this has been established in hundreds of separately conducted studies.

Breast cancer is one of the commonest cancer in women across the world and is on rise in our country too. It has a very bad prognosis if detected at later stages and can be life threatening. The exact causative factor behind the occurrence of breast cancer is not recognized yet, but it has genetic basis which has been thoroughly researched and proved. Mammary buds are formed during intrauterine life around $6^{\text {th }}$ week as solid downgrowth of the epidermis in the mesenchyme lying beneath it [4].This means that the genetic information contained in the genome whether normal or abnormal is translated during this period and is also reflected by epidermal ridge patterns on hands [5].

Preceding studies on dermatoglyphics have given us the proof that it can be used to assess the risk of developing many diseases with genetic background. So palmar patterns can act as an efficient anatomical marker to screen the breast cancer cases at an early stage. It's significance lies in its inexpensive and harmless nature and it can be done under any setting or place. It may be used to screen the females at risk among general population and help medical personnel to give timely advice to them to go through further established investigations to diagnose breast cancer.

\section{MATERIALS AND METHODS}

This study was conducted on 109 diagnosed and histopathologically confirmed female cases of breast cancer within the age group of 18 to 70 years attending the Radiotherapy department of Government Cancer Hospital, Indore. Similarly 109 age matched normal healthy female controls with no family history of cancer or any other genetic disorder were selected from female students and staff members of Mahatma Gandhi Memorial Medical College and M.Y. Hospital, Indore and female attendants of cancer patients. Subjects with inheritable disorders other than breast cancer like Diabetes, hypertension, schizophrenia or mental retardation were excluded from the study. Informed consent was taken from both groups. Palmar patterns were taken by Ink method as described by Cummins and Midlo [6].

According to ink method first the hands of the subjects were washed properly with soap and water and any greasy material was removed with spirit, after drying, hands were placed over the ink pad and the palm was smeared uniformly with the ink to evenly cover the entire area of the palm which had to be printed for the examination. Impression of both the hands were obtained on a A4 size white paper kept on the hard table top by placing the palm firmly upon the paper and applying slight pressure over the dorsum of the hand especially intermetatarsal areas so that a uniform palmar print can be obtained, the recorded patterns were studied using a magnifying lens. $a-b$ ridge count and palmar angles like 'atd' angle and 'adt' angle were measured and analysed after identifying dermatoglyphic landmarks of palm like triradii (a, b, d and t) (figure 1) .

TRIRADIUS: It is formed by the union of three ridge systems. The geometric center of the triradius is called as triradial point [7] (figure 1). There are two types of triradius present on the palm :-

1. Digital triradius - These are the triradius present near the bases of the fingers, they are named $a, b, c$, and $d$ triradius (figure 1 ).

2. Axial triradius - This triradius is found near the proximal margin of the palm, in the hollow between thenar and hypothenar eminences, its position is variable and named as ' $t$ ' triradius (figure 1)

Ridge counting between ' $a$ ' and ' $b$ ' digital triradii was done to get $\mathbf{a}-\mathbf{b}$ ridge count, the counting is done along a straight line connecting the two triradial points, the ridges containing the triradial points are both excluded from the count, it is the most frequently taken ridge count in the palm [8] (figure 2).

'atd' angle and 'adt' :- These angles were obtained by lines drawn from the digital triradius (a) to the axial triradius ( $t$ ) and from this triradius to the digital triradius (d) [7] (figure 2). For each subject palmarprints of both hands were obtained. Overall 109 palmarprints of right hand and 109 prints of left hand for both cases and controls were taken seperately for analysis. For comparison of the data i.e. mean a-b ridge 
count, mean atd angle and mean adt angle between both the groups $t$ - test was used.

Fig. 1: $a, b, d$ and t triradii on palm.

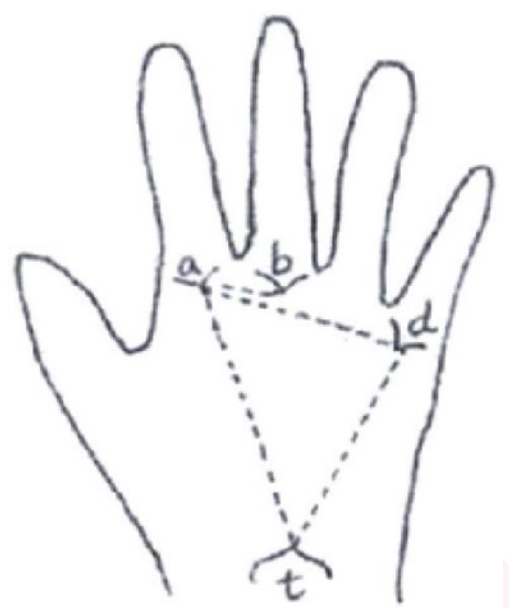

Fig. 2: Palmar print showing a-b ridge count, atd and adt angles.

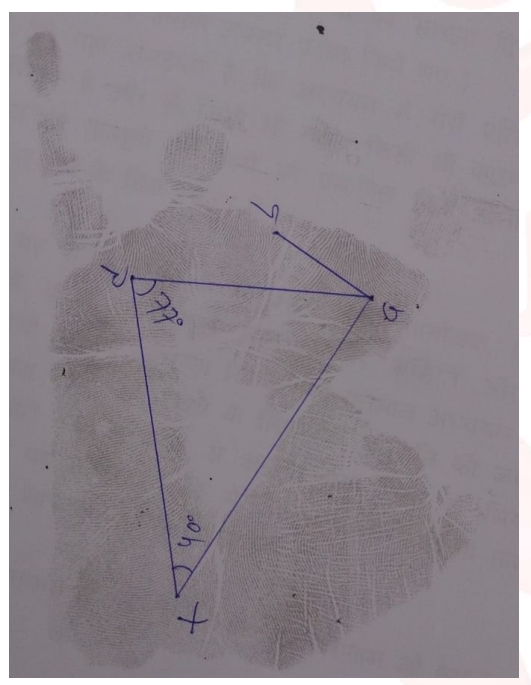

\section{RESULTS}

On comparing the mean $a-b$ ridge count of right and left hands of both the groups, it was observed that there is statistically significant difference between mean $a-b$ ridge count in right hand of cases (27.59) and controls (31.08) with $P$ value $<0.05$, Similar statistically significant difference was observed in mean $a-b$ ridge count of left hand of cases (28.5) and controls (32.87) with $P$ value $<0.05$ (Table 1).

Table 1: Comparison of mean of a-b ridge count of right and left hand of both the groups.

\begin{tabular}{|c|c|c|c|c|}
\hline \multirow{2}{*}{ Group } & \multicolumn{2}{|c|}{ Right hand } & \multicolumn{2}{c|}{ Left hand } \\
\cline { 2 - 5 } & Mean & $\begin{array}{l}\text { Standard } \\
\text { deviation }\end{array}$ & Mean & $\begin{array}{c}\text { Standard } \\
\text { deviation }\end{array}$ \\
\hline Cases(n=109) & 27.59 & 4.84 & 28.5 & 5.83 \\
\hline Controls(n=109) & 31.08 & 5.26 & 32.87 & 5.87 \\
\hline P Value & \multicolumn{2}{|c|}{0.00000075} & \multicolumn{2}{|c|}{0.0000001} \\
\hline Significance & Extremely significant & \multicolumn{2}{c|}{ Extremely significant } \\
\hline
\end{tabular}

Whereas comparison of mean atd angle of right and left hands in both groups respectively demonstrated that in right hand there is no significant difference in mean atd angle of cases and controls ( $P$ value $>0.05$ ). In left hand also there was no significant difference observed in cases and controls ( $P$ Value $>0.05$ ) (Table 2).

Table 2: Comparison of mean of atd angle of right and left hand of both the groups.

\begin{tabular}{|c|c|c|c|c|}
\hline \multirow{2}{*}{ Group } & \multicolumn{2}{|c|}{ Right hand } & \multicolumn{2}{c|}{ Left hand } \\
\cline { 2 - 5 } & Mean & $\begin{array}{c}\text { Standard } \\
\text { deviation }\end{array}$ & Mean & $\begin{array}{c}\text { Standard } \\
\text { deviation }\end{array}$ \\
\hline Cases(n=109) & 42.44 & 4.68 & 42.62 & 4.81 \\
\hline Controls(n=109) & 43.16 & 5.59 & 43.96 & 5.48 \\
\hline P Value & \multicolumn{2}{|c|}{0.3037} & \multicolumn{2}{|c|}{0.056} \\
\hline Significance & \multicolumn{2}{|c|}{ Not significant } & \multicolumn{2}{c|}{ Not significant } \\
\hline
\end{tabular}

Similarly on comparison of mean adt angle of right and left hand in both groups respectively, it was observed that in right hand of cases and controls there was no significant difference ( $P$ Value $>0.05$ ). Similarly in left hand of both the groups there was no significant difference observed (P Value > 0.05) (Table 3).

Table 3: Comparison of mean of adt angle of right and left hand of both the groups.

\begin{tabular}{|c|c|c|c|c|}
\hline \multirow{2}{*}{ Group } & \multicolumn{2}{|c|}{ Right hand } & \multicolumn{2}{c|}{ Left hand } \\
\cline { 2 - 5 } & Mean & $\begin{array}{l}\text { Standard } \\
\text { deviation }\end{array}$ & Mean & $\begin{array}{l}\text { Standard } \\
\text { deviation }\end{array}$ \\
\hline Cases $(\mathrm{n}=109)$ & 79.04 & 3.8 & 78.76 & 5.99 \\
\hline Controls $(\mathrm{n}=109)$ & 78.53 & 4.18 & 78.65 & 3.99 \\
\hline P Value & \multicolumn{2}{|c|}{0.347} & \multicolumn{2}{c|}{0.87} \\
\hline Significance & \multicolumn{2}{|c|}{ Not significant } & \multicolumn{2}{c|}{ Not significant } \\
\hline
\end{tabular}

\section{DISCUSSION}

About a-b ridge count: Luis de Andres Basauri (1975) in his study found that a-b ridge count was less in cases as compared to control group [9]. Yunyu Zhou et al., (2001) found that average $a-b$ ridge count is significantly lower in breast cancer patients [10]. Whereas Prashant E. Natekar, Fatima M. Desouza et al., [11] and N.S. Sridevi et al.,[12] found $a-b$ ridge count significantly more in breast cancer patients than in control group. S.P. Fulari et al. (2012) also found $a-b$ ridge count higher in cases than control group [13]. In our study mean a-b ridge count on both left and right hands of breast cancer cases is significantly lower than mean $a-b$ ridge count of controls.

About atd angle: Prashant E. Natekar, Fatima M. Desouza et al., [11] and D. Madhavi et al.,[14] 
found less atd angle in breast cancer patients. S.P. Fulari et al., [13] found that mean atd angle was higher in breast cancer patients as compared to controls. Whereas in our study there was no significant difference between mean atd angle of cases and controls in both hands.

About adt angle: N.S. Sridevi et al. (2010) found significantly lesser mean adt angle in both hands of breast cancer patients than controls [12]. SukreeS.B in 2004 studied dermatoglyphics in 50 breast carcinoma patients and 50 controls and concluded that there was no significant difference in adt angle [15]. Similarly D. Madhavi et al., (2016) also didn't found any significant difference in mean adt angle of cases and controls [14], there was no significant difference found between mean adt angle of cases and controls in both hands in our study also. Results of our study for adt angle coincides with above mentioned last two studies but not in agreement with the results of N.S. Sridevi et al., [12].

The differences in results in the various studies may be due to involvement subjects belonging to different racial groups and geographical areas.

But still some studies like one conducted by UduakUmana et al., (2013) on 100 histopatholgically proven cancer cases out of which only 18 had carcinoma breast and compared their Dermatoglyphic and Cheiloscopic findings with 126 normal subjects [16]. They observed positive correlation between dermatoglyphics and carcinoma breast and negative correlation between cheiloscopic findings. This positive correlation even in a small study group demands attention. All the studies including ours, conducted till date have found positive correlation between carcinoma breast and dermatoglyphics. Thus it may serve as a predictor tool for breast cancer and can easily mark the people at risk from general population.

\section{CONCLUSION}

This study was conducted to evaluate any important difference between the palmar patterns of breast cancer patients and healthy subjects and it has been observed that there is a possible positive correlation between fingerprint patterns and breast cancer. So palmar patterns could be helpful in screening the female at risk who may be guided to undergo mammography and to rule out or diagnose the chances of developing breast cancer in future, it will help us to take preventive prophylactic measures like prophylactic surgery or chemoprevention. Though in order to designate a specific palmar pattern that could be pathognomonic of breast cancer, study of other dermatoglyphic landmarks along with the one's used in this research on larger population groups belonging to different topographical areas is needed.

\section{Conflicts of Interests: None}

\section{REFERENCES}

[1]. Henry ER. Classification and uses of finger prints. 8thed. London: HM. Stationary Office 1937:1-45.

[2]. Babler W. Embryologic development of epidermal ridges and their configurations. In: Dermatoglyphics: Science in transition. Birth defects (Edited by: CC P, RM G, BA S). Wiley-Liss: New York; 1991. p. 95112 .

[3]. Moore K L, Persaud T V N ,Torchia M G.The Developing Human: Clinically oriented embryology. $9^{\text {th }}$ edition. Elsevier Publication;2016: 438.

[4]. Moore K L , Persaud T V N , Torchia M G .The Developing Human: Clinically oriented embryology. $7^{\text {th }}$ edition. Elsevier Publication; 2004:492-3.

[5]. Balgir RS.Congenital oral clefts and dermatoglyphics. ISRJ Med Sci .1984;20:622-4.

[6]. Cummins $\mathrm{H}$ and Midlo WC. Fingerprints, Palms and Soles: An Introduction to Dermatoglyphics. 2nd edition. New York: Dover Publication. 1961:1-319.

[7]. Schaumann B and Alter M. Dermatoglyphics in medical disorders. New York: Springer 1976:22-87.

[8]. Dr.Pratibha Ramani et al.: Conventional Dermatoglyphics- Revived concept: A Review; Vol 2/Issue 3/Jul-Sept2011

[9]. Luis de Andres Basuri. Identification of high risk group by means of Dermatoglyphic investigation. Genetic Factors in Breast Cancer Oncology. 1975;32: 37-43.

[10]. Yunyu Zhou, YanjunZeng, Lizhen, Wenlei Hu. Technology and Health Care. 2002;10:383-390.

[11].PrashantE. Natekar, Fatima M. And De Souza. Fluctuting asymmetry in dermatoglyphics of carcinoma of breas. Indian Journal of Human Genetics. May - august 2006;12(2):76-81.

[12].N S Sridevi, C R Wilma Delphine Silva, RoopaKulkarni,C.Seshagiri. Romanian Journal of Morphology and Embryology. 2010;51(3):547-550.

[13]. S P Fulari, M MPirzade, AshwiniJadhav. Study of dermatoglyphics in breast cancer. National Journal of Medical Sciences. 2012(JAN); 1(1):29-32.

[14]. Madhavi D et al. Dermatoglyphic study in Breast carcinoma patients. IJSR. 2016;5(10):837-40. 
[15]. S.B.Sukree, AAMahajan. Dermatoglyphics in the identification of women either with or at risk for breast cancer. 51st journal of Anatomical society of India. 5(1); 2004-01; 2004-06.

[16]. UduakUmana C O, Ahunna J A, Timbuak A O, Ibegbu $S$ A, Musa,W O Hamman. Dermatoglyphics and Cheiloscopic Patterns in Cancer Patients: A Study in Ahmadu Bello Univer-sity Teaching Hospital (ABUTH), Zaria, Nigeria. Current Re-search Journal of Biological Sciences. 2013;5(5):220-225.

How to cite this article:

Prateek Shrivastava, Ankit Jain. STUDY OF PALMAR PATTERNS IN CARCINOMA BREAST PATIENTS OF CENTRAL INDIA. Int J Anat Res 2019;7(2.2):6504-6508. DOI: 10.16965/ijar.2019.152 